\title{
Religion Classes at Russian Schools: Reasoning and Thoughts
}

\author{
E.V. Gromov, Sergey V. Smirnov
}

\begin{abstract}
The problem of religious revival in Russia and the development of Russian re-ligious culture after the fall of the Soviet ideological system in 1991 is one of the urgent and intensively developed problems of modern social philosophy. In a country where for several decades all forms of religious life were banned, and any religiosity was subjected to obvious ( Lenin, Stalin and Khrushchev) or hidden (in the last years of the USSR) persecution, religious consciousness was not only not suppressed. But it is also awakened with unprecedented strength before, becoming one of the determining factors of the political and spiritual life of the entire post-Soviet space. The full significance of this phenomenon has not yet been revealed by history and philosophy, but without understand-ing it now it is impossible to imagine the dynamics of the processes taking place in our country. One of these processes is the adaptation of the educa-tional space of Russia to the new spiritual picture of society, and the most im-portant aspect of it can rightly be considered the discussions around the newly introduced school discipline "Fundamentals of religious culture and secular ethics", reflecting almost in its entirety the modern ideological state of the Rus-sian pedagogical community, and, in part, and society as a whole. This article is an attempt to answer the questions: how was the current concept of school religious education formed? Should it be religious or religious studies and cul-tural? What are the main principles of this concept? How does the practice of its implementation comply with these principles? What is the perception of this innovation in Russian society, and, in particular, in the educational space? And finally, what are the prospects for this new trend in Russian education? To solve the problem, such methods as analysis, synthesis, induction, deduc-tion, and the unity of the historical and logical were used. In the course of the research, the main approaches to teaching the fundamentals of religious culture that take place in the Russian educational space (secular ethics included in the new course were initially viewed as a politically correct appendage to its main religious content) were identified, the main trends in Russian educational poli-cy related to the problem of religious culture and its compatibility with the principle of secular education, identified some prospects for further research. An analysis of the problem leads to the conclusion that, on the one hand, the need to integrate religious education into the educational system of Russia is long overdue, on the other - that the current solution does not suit any of the parties to this process. The principles of selectivity and confessional orienta-tion of the modules of the new discipline cannot be fully implemented, the con-tent of the curricula does not correspond to the goals of religious studies, a clear understanding of which, moreover, is lacking.
\end{abstract}

Keywords: religion, ethics, religious studies, religious consciousness, secular education.

Revised Manuscript Received on September 22, 2019

* Correspondence Author

E.V. Gromov , Kazan Federal University, Russia

Sergey V. Smirnov Kazan Federal University, Russia

\section{INTRODUCTION}

In this article we will try to answer the question about the perception in the Russian public consciousness of such a major innovation in the Russian educational system as the introduction of a large thematic block into the school curriculum, the modules of which are designed to familiarize schoolchildren with the choice of their parents. This problem has arisen only in the last few years, and has not yet had time to become the subject of large-scale sociological and philosophical research, but its relevance is not in doubt both among the majority of the Russian pedagogical community and among representatives of religious organizations involved in this process. At present, when the first experience of introducing a religious study block into the school curriculum has already been accumulated, and the intensity of public discussions around it has noticeably decreased, favorable conditions arise in order to comprehend this innovation, including its social and philosophical aspects.

In the course of the study, we analyzed the results of very fierce discussions that unfolded around the discipline "Fundamentals of religious cultures and secular ethics" (FRCSE) starting from its introduction as an experiment in some regions of Russia in 2010, as well as around the experience that preceded this undertaking Elective discipline "Fundamentals of Orthodox Culture." Also analyzed were the trends in world philosophy that understood the place and role of religions in the modern educational space and the mapping of these trends in Russian philosophical thought.

\section{METHDOLOGY}

During the study, the following methods were used: analysis, synthesis, induction, deduction, the unity of historical and logical. Analysis and synthesis of the tendency of understanding the place and role of religions in the modern educational space. Deduction and induction were used to determine the essence of the school religious education. The method of unity of historical and logical was used to characterize the prospects for religious studies modules in the context of the further development of education in Russia.

\section{DISCUSSION.}

In recent years, Russia has been widely debating the issue of the inclusion in the school curriculum of a new thematic unit called "Basics of Religious Culture and Secular Ethics". Initially, the purpose of its introduction was to introduce students to the traditional values of the cultural-forming religions of Russia, and the initiative of the first attempts in this area came from the country's largest religious organization, the 
Russian Orthodox Church. The experience of this discussion revealed a whole series of problems that had already been raised in the Russian and world philosophy of education, but on a number of aspects that had not been revealed so far. First of all, it became necessary to determine the boundary beyond which the culturological training course turns into the teaching of the foundations of religion, and to decide on the possibility of teaching subjects with religious pressure in a secular school. Rapid changes in intercultural relations in recent decades, the crisis of traditional religiosity of the West, the accelerated emergence of a multi-religious environment in a number of countries and the exacerbation of inter-religious conflicts around the world make this problem relevant not only for Russian, but also for world philosophy, reflecting the current situation of deepening spiritual crisis of world civilization [15].

The problem of school religious education in the conditions of a secular state is developed, in comparison with other problems of the philosophy of education, is relatively weak. In world philosophical practice, it is usually considered in aspects of the methodology of teaching the basics of religion and religious studies, or the formation of interfaith tolerance within the framework of school religious and religious studies. A number of authors, in particular Beth Green, in the article "The Contours for Research Religion and School Choice" [4], focus primarily on factors that influence the choice between religious schools and secular educational institutions. The aforementioned author, in particular, comes to the conclusion that the choice of religion as a worldview, and the choice in favor of religious education are often motivated by different reasons. This is only partly applicable to the Russian reality, in which much more often it is about choosing between public school disciplines with different religious intensity. The use of religious education in schools for the promotion of religious fundamentalism, on the one hand, and, on the other, opposition to the latter, is discussed in specialized publications, as exemplified by the article Akhmad Shunhaji [2]. The problems of teaching natural sciences in religious schools are widely discussed, in particular, in the article by Albert Cheng [3], the experience of teaching the foundations of religion in municipal and public schools, their influence on the moral development of young people, to which David R. Dupper, Jotandre, and David R. Pandya and several other authors [5, 7, 10]. A number of researchers are attracted by the problem of the development of religious culture in post-Soviet Russia, especially the evolution of religious organizations and their role in public life. So, Agata Ładykowska considers the current system of Sunday schools of the Russian Orthodox Church as the main means of religious education of believers after the collapse of the USSR [1]. Martin Ubani in his article "Evolving classes of religious education: new perspectives on research, policies and practices" analyzes the problems and perspectives of religious education in the modern world, however, without paying attention to Russian specifics [8]. In Russian philosophy and pedagogy, priority is given to the methodological aspects of the problem. The general theoretical issues of teaching FRCSE in public schools in Russian philosophy are covered relatively poorly. We can note the article by M. Smirnova in the collective monograph "Religious Perspectives from 32 Legal Systems", which, in particular, analyzes the approaches to the basics of religious culture in a public school and religious schools [13]. A number of publications are devoted to the use of FRCSE in the spiritual and moral education of schoolchildren, in particular, the article by T.A. Fedotova [20].

The specificity of school religion in modern Russia lies primarily in the unique historical context in which it emerged and develops. Its emergence is one of the many aspects of religious revival in Russia and throughout the post-Soviet space, periodically becoming reasons for public debate. The contradictory attitude of society towards this rebirth is connected with many factors. First of all, we should not forget that until the mid-eighties of the last century, Russia was part of a rigidly structured ideological space in which compulsory atheism was imposed by means of state power. The generations that now occupy most of the most important positions, including in the education system, have found, in one degree or another, an era when atheistic education of students was an obligatory part of school education (the authors of these lines themselves still remember the obligatory class hours and open lessons in junior classes devoted to anti-religious propaganda). During the rule of atheistic ideology, everyday atheism has spread throughout society, and many cliches of anti-religious propaganda have become the property of popular culture. At the same time, many representatives of these generations, even without being adherents of the communist doctrine, retain their ideas about the anti-scientific nature of religious faith and the incompatibility of religious institutions with a democratic, free society. This conflict of ideological and religious discourses, still continues to have a significant impact on public opinion in matters of school religion. Thus, already at the early stages of the discussion, L. Usykin, one of its most active participants, criticizing the position of supporters of introducing a new subject block into the school curriculum, represents the position of the Orthodox part in full accordance with the paradigms of Soviet atheism: “... Orthodox tradition since the time of Julian the Apostate call any situation when the church does not have a privileged status. Confessional equality is also a persecution of the church "[19].

Another important factor that influenced the formation of the concept of school religion was the intensive modernization of Russian society since the nineties. The leitmotif of this modernization was the political and cultural rapprochement of post-Soviet Russia with the Western world, announced as far back as the era of perestroika, and in a number of areas (including education) that has continued, despite all the political changes of recent years, to the present. This convergence occurs under conditions where the ideas of postmodernism are spread throughout the civilization of the West, in particular, the "deconstruction of discourses" proclaimed by its founders. The latter, in turn, implies the deconstruction of religious discourse, which predetermines the intellectual fashion of anti-religion and anti-churchism, expressed, inter alia, in the spread of neo-pagan cults and frank mockery of Christian shrines and the very foundations of the Christian faith [12]. Accordingly, the introduction of disciplines in the school with a pronounced religious load could not but cause their rejection in a part of the representatives of the Russian intelligentsia, subject to Western cultural "trends".

On the other hand, this discussion was attended primarily by representatives of a number of religions and confessions of Russia, and not 
only from the clergy (in those religions where there is an institute of the clergy), but also from the religious community, those who in the Christian tradition are called laymen. Initially, the initiative to create a new school discipline came from the Russian Orthodox Church: in 1999, at the suggestion of Patriarch of Moscow and All Russia Alexy II, an agreement was concluded between the Ministry of Education and Science of Russia and the Moscow Patriarchate to collaborate in introducing the Orthodox Culture discipline into the school program (or "Basics of Orthodox Culture"). Thus, in the modern Russian concept of school religion, the influence of the most widespread religious organization in our country prevailed. This influence is also reflected in such confessionally neutral documents as methodological recommendations on the subject, published by the Ministry of Education and Science, in which, as a rule, Orthodox culture is mentioned in the first place [17].

We believe that the formulation of the question of introducing such a discipline was historically logical, as was the fact that it was the Russian Orthodox Church that took the initiative. Religious revival, which accompanied the fall of the communist regime, was quite naturally accompanied by the growth of the influence of religion on various aspects of public life. The theme of the cultural roots of religion, as well as the theme of the participation of the Church in Russian history, has ceased to be taboo, the mass restoration of closed and destroyed temples, Orthodox monasteries, mosques, synagogues and datsans once again made religious activity an integral part of public life, and the priest again did not only visible, but also a familiar member of society. The result was a growing interest in issues of religious traditions and religious culture, encompassing all sectors of society. The initiative of the Sunday school was a response to this process, and it reflected the deeply rooted traditions of cooperation with the government. The essence of the proposal was primarily a compromise between the hopes of many believers for the return of religious education to schools and the prevailing opinion in the educational system about the inadmissibility of teaching religious knowledge in a secular school. The purpose of the new subject was to give Orthodox schoolchildren the opportunity to get acquainted with the history and cultural traditions of their religion under the guidance of professional teachers during their studies in a secondary school. Such an acquaintance so far occurred, as a rule, either during family upbringing, or within the framework of a Sunday school, which created a number of inconveniences. First, the parents of students, even as believers, as a rule are not experts in the field of religious culture, and cannot satisfy the cognitive demands of their children. Secondly, Sunday schools do not exist in all parishes, in the same place where they are, not certified teachers teach them, but clergymen who do not always have the necessary pedagogical skills, and in some cases who have little knowledge of the culturological component of their faith. Thirdly, the need to attend Sunday school leads to an increase in the academic load on believing schoolchildren in comparison with children from atheistic families, in fact, occupying the only day off of the schoolchild.

The further history of the new subject block is a series of compromises between religious communities, state power and the public. Within the framework of one article, it is impossible to trace the whole process, however, it should be noted that the first results of the trial implementation of
"Fundamentals of religious culture and secular ethics" in 19 regions of Russia in 2010-2012 are the same, as well as even earlier attempts to introduce " Fundamentals of Orthodox Culture "in certain regions of Russia, revealed sharp differences in opinions on this issue between different social groups. Opponents of this bloc saw in him the threat of clericalization of Russia, argued about the incompatibility of teaching such a subject in a public school with the principle of secularism of the state guaranteed by the Constitution, and expressed opinions about the threat of inter-religious conflicts being included in the school. For their part, representatives of various religions pointed out that religious education in public schools is practiced in many countries of modern Western Europe, that the right to receive religious education is guaranteed by the current Federal Law on Religions, tried to convince the public that The introduced course is focused on the upbringing of religious tolerance and the introduction of schoolchildren to traditional moral values and that teaching religious culture will affect only children, brought up in the spirit of a particular religion. At the same time, both sides actively accused each other of abusing the implementation of this block of disciplines in schools, mainly in attempts to influence the choice of parents of the discipline for their children either in favor of the Fundamentals of secular ethics, or in favor of the Fundamentals of Orthodox Culture (disciplines associated with other religious traditions in such accusations appeared much less frequently) [18;19]. In general, we can note a certain decrease in the intensity of the discussion in the last year and a half, which is reflected, in particular, in the decline of the critical intensity of publications in the media on this topic. Thus, in secular electronic publications, which were recently quite unconditionally critical of teaching the fundamentals of religious culture in public schools, there are articles with a more benevolent attitude to the new discipline. An example is the article of S. Dzyubenko, the author of which, in particular, notes that the teaching of subjects with religious content in the school program "... does not contradict world practice" [16].

In the course of this discussion, by 2014 , the main features of modern Russian school religion, which can be formulated as follows:

1. Religious education at school is not intended to teach religion, but to introduce students to the spiritual foundations of traditional cultures of Russia, and is part of the culturological and patriotic education of schoolchildren. A number of critics of the new subject block indicate that the existing textbooks and curricula on the basics of various religious cultures were not written by cultural scientists, but by religious figures, and focused directly on teaching the dogma of a particular religion. As a rule, this is objected to, that the foundations of the spiritual culture of religion from its dogma are inseparable.

2. The principle of voluntary choice of discipline related to a particular religion or ("Fundamentals of secular ethics") completely devoid of religious content is the basis of school religion. This preserves the equality of the academic load on all children, regardless of religious affiliation, however, this principle comes into a certain contradiction with the previous one (culturological familiarity with religion is possible regardless of the subject's own views).

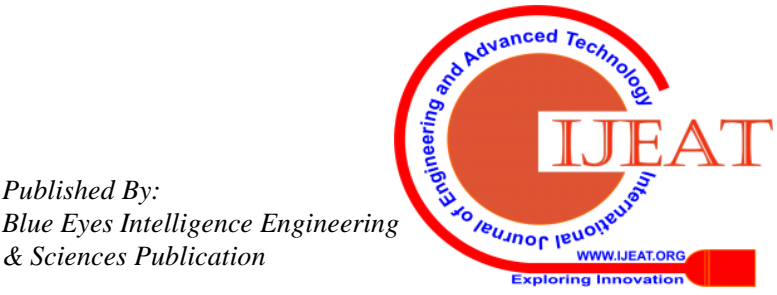


3. The main educational goal of the newly introduced subject block is the education of interreligious and intercultural tolerance. The urgency of this goal is due, among other things, to the peculiarities of the mentality of the Russian person, in which, as noted by A.G. Sabirov and L.A. Sabirov, paradoxically, tolerance coexists with intolerance [9].

4. School religion is part of the federal component of the educational program, and thus becomes a part of state policy, both in the field of education and in the field of interaction between the state and religious organizations. Accordingly, a certain unified position is assumed on the main key issues, such as the objectives of the program, its content, the specifics of implementation in accordance with the model of practice-oriented learning currently being developed [11]. The model that emerged during the 2010-2012 experiment differs from the initial attempts to introduce the discipline "Basics of Orthodox Culture" when it was considered as part of the regional component.

5. Instead of the originally intended introduction of religious education throughout the entire school curriculum, the subject "Basics of Religious Culture and Secular Ethics" was introduced only in grades 4-5. This decision can be viewed as a compromise between supporters and opponents of religious education in a public school. However, in the end, neither of them was satisfied: the supporters of the subject express their wishes to extend it to other classes, the opponents demand its exclusion from the program or transformation into a purely religious study or historical discipline.

It should also be noted that these principles, firstly, do not represent a certain formal doctrine, but are generalized conclusions from the practice of introducing disciplines with religious content into the school curriculum; secondly, by now they are still in the process of becoming, and in the course of further development, the problems may undergo significant changes. Taking into account the trends that emerged in 2010-2018, it can be assumed that the practice of compromises between various parties to the discussion will be further developed, which will lead, on the one hand, to the strengthening of theological and culturological components, on the other - in a more clearly defined orientation of specialized disciplines satisfaction of the cognitive demands of believing schoolchildren and their parents, their correlation with the goals of personal and professional growth [6].

\section{CONCLUSION}

In the course of the research, the main trends in the development of the concept of religious and religious education in the state general education school of modern Russia were identified, the main provisions of the concept of such education, identified during the public discussion around the subject block "Fundamentals of religious culture and secular ethics ", Outlined the immediate prospects for the development of the problem. At the same time, a number of problems have been identified that can be solved in the course of further research.

\section{REFERENCES}

1. Agata Ładykowska. The changing scope of religious authority and reconfigurations of social status in post-socialist Russia. Journal Religion, State and Society Volume 46, 2018 - Issue 2: Public
Religions After Socialism: Redefining Norms of Difference. URL: https://www.tandfonline.com/doi/full/10.1080/09637494.2018.145843 0. Date Views 22.11.2018

2. Akhmad Shunhaji. Islamic Religion Education Implementation in Catholic School Blitar City, East Jawa and the Impact on Participants of Social Interaction. Journal of Education and Practice. Vol.9, No.36, 2018. URL https://iiste.org/Journals/index.php/JEP/article/view/45784 Date Views 17.11.2018.

3. Albert Cheng. The educational emphases of science teachers in US Evangelical Protestant high schools. International Journal of Christianity \& Education. URL https://journals.sagepub.com/doi/full/10.1177/2056997118812906. Date Views: 13.01.2019.

4. Beth Green. The Contours for Researching Religion and School Choice. Journal Religion, State and Society Volume 46, 2018 - Issue 4: Special Issue on Religion and School Choice. URL: https://www.tandfonline.com/doi/abs/10.1080/15582159.2018.152422 9 Date Views 15.11.2018

5. David R. Dupper, Shandra Forrest-Bank, Autumn Lowry-Carusillo. Experiences of Religious Minorities in Public School Settings: Findings from Focus Groups Involving Muslim, Jewish, Catholic, and Unitarian Universalist Youths. Children \& Schools, Volume 37, Issue 1, 1 January 2015, Pages 37-45. URL: https://doi.org/10.1093/cs/cdu029 . Date Views: 14.09.2018.

6. Gray K. Workforce education: The basics / K. Gray, E. Herr. - Needham Heights, MA: Allyn and Bacon, 1998. - 326 p.

7. Joan Letendre, Jason A. Ostrander, Alison Mickens. Teacher and Staff Voices: Implementation of a Positive Behavior Bullying Prevention Program in an Urban School. Children \& Schools, Volume 38, Issue 4, 1 October 2016, Pages 235-243. URL: https://doi.org/10.1093/cs/cdw032 . Date Views: 11.09.2018.

8. Martin Ubani. Evolving cultures of religious education: new perspectives on research, policies and practices. Journal of Beliefs \& Values. Studies in Religion \& Education Volume 39, 2018 - Issue 2. URL: https://www.tandfonline.com/doi/full/10.1080/13617672.2018.147289 4 Date Views 16.12.2018

9. Sabirov A.G., Sabirova L.A. Toleration And Intolerance In Mentality Of Russian Man. European Proceedings of Social and Behavioural Sciences Volume XXXV (35) eISSN: 2357-1330. URL: https://www.futureacademy.org.uk/files/images/upload/icRPTSS2017F A132.pdf. Date Views 20.11.2018

10. Samta P. Pandya. Spirituality and Values Education in Elementary School: Understanding Views of Teachers. Children \& Schools, Volume 39, Issue 1, 1 January 2017, Pages 33-42. URL https://academic.oup.com/cs/article-abstract/39/1/33/2527540?redirect edFrom=fulltext. Дата обращения: 14.09.2018.

11. Sergei Vladimirovich Smirnov, Aiziriak Nailevna Tarasova Practice-based learning: essence, methodology of updating Special Issue, №1. Medellín-Colombia pp. 1583-1588 URL:http://revistas.proeditio.com/iush/quid/article/view/2029/2037

12. Sergey V. Smirnov. Modern Anthropological Decadence: Sources, Essence and Ways to Overcomte. The Social Sciences, 10, pp 1756-1759.

URL:http://medwelljournals.com/abstract/?doi=sscience.2015.1756.17 59

13. Smirnova M. Russia - Religious Attire and Religious Instruction in Public Schools. Freedom to Open Non-State Religious Schools Religious and Ideological Rights in Education: Judicial Perspectives from 32 Legal Systems. Academic editor: J. De Groof, P. M. Cereceda. Nijmegen: Wolf Legal Publishers, 2017. P. 275 - 289.

14. Suzanne Rosenblith. Religion in Schools in the United States. Oxford research enciclopedias: Education. URL: http://oxfordre.com/education/view/10.1093/acrefore/9780190264093. 001.0001/acrefore-9780190264093-e-46 . Date Views: 11.09.2018.

15. Valtsev, S.V. The decline of mankind. Why are you humanity born? - M : Book World, 2010. - 384 p.

16. Dzyubenko S. Religion at school and secular state / Political education: an information and analytical journal. URL: http://lawinrussia.ru/content/religiya-v-shkole-i-svetskoe-gosudarstvo. The date of processing: 10/18/2018. 
17. Guidelines for the executive authorities of the constituent entities of the Russian Federation to improve the process of implementing the comprehensive training course "Basics of religious cultures and secular ethics" and the subject area "Basics of the spiritual and moral culture of the peoples of Russia". City Methodical Center. URL: http://mosmetod.ru/metodicheskoe-prostranstvo/odnknr/normativno-pr avovaya-dokumentatsiya/pismo-minobrnauki-rossii-ot-19-01-2018-g-0 8-96-o-metodicheskikh-rekomendatsiyakh-odnkr. html. Appeal date: September 15, 2018.

18. Archpriest Vladislav Tsypin. On the teaching of "Fundamentals of Orthodox Culture." Orthodoxy.Ru. URL: http://www.pravoslavie.ru/693.html. Appeal date: September 15, 2018.

19. Usykin L. Basics of religious cultures and secular ethics. First year of study. Polit.Ru. URL: https://polit.ru/article/2013/02/25/books/. Appeal date: September 15, 2018.

20. Fedotov, T.A. Possibilities of the course "Fundamentals of Religious Cultures and Secular Ethics" for the personal development of younger students / Science in the city. URL: https://mgpu-media.ru/issues/issue-6/psycho-pedagogical-science/basi cs-of-religious-cultures.html. Appeal date: September 15, 2018. 